\title{
Judicialization or Renunciation? Judges in Today's Landscape of Anti-Terrorism Laws
}

\section{By Grant R. Hoole ${ }^{\star}$ and Rebecca Ananian-Welsh ${ }^{\star \star}$}

Judges in constitutional democracies face common dilemmas navigating today's landscape of anti-terrorism laws. Whether it is with respect to the oversight of investigative detentions or approval of control orders, security certificates, and other official powers calculated to investigate and prevent terrorism and related activities, the judicial role has expanded into fields where the appropriate balancing of security concerns with individual liberties is exceedingly complex. The need for such balancing is, of course, one of the central justifications for judicial involvement: the judiciary is relied upon to bring characteristic independence and integrity to the review of official powers, ensuring compliance between the latter and the higher law of the Constitution. There is nevertheless an unsettling implication that sometimes attends judicial service in these fields - namely, it is not always clear whether the judicial role is truly one of constitutional enforcement and oversight, or one that allows administrative actors to borrow the integrity of the courts in furtherance of constitutionally-suspect ends. ${ }^{1}$

This concern is brought into sharp relief by powers legislatively conferred on officials of Australia's Security Intelligence Organisation (ASIO) since $9 / 11$, and new ones intended for officials of Canada's Security Intelligence Service (CSIS) in Bill C-51, ${ }^{2}$ the most recent iteration of Canada's anti-terrorism laws. Both of these legislative regimes engage judges in ostensible oversight roles, but also raise troubling implications for their independence and for public confidence in the judiciary. The Constitutions of each country present distinct obstacles and potential solutions to this challenge. A comparison of their respective positions helps illuminate possible ways forward for each.

Australia and Canada share constitutional origins as the descendants of British colonial states, yet their Constitutions are marked by significant differences. While both countries are Westminster-style parliamentary democracies observing a relatively weak separation of powers between the executive and legislative branches of government, Australia enforces a strict separation between the judiciary and the political branches. The High Court observed in its landmark 1956 decision in $R v$ Kirby; Ex parte Boilermakers' Society of Australia3: "A federal constitution must be rigid. The government it establishes must be one of defined powers; within those powers it must be paramount, but it must be incompetent to go beyond them." ${ }^{4}$ By virtue of Australia's federal judiciary being vested with distinct powers under Chapter III of the Commonwealth Constitution, the courts have inferred that federal judicial powers are both exclusive and exhaustive: no authorities other than federal courts may exercise those powers, and federal courts themselves may not exercise 
powers that are not formally "judicial." This principle results in federal courts being barred from functions sometimes exercised by the judiciaries of other countries, such as the provision of advisory reference decisions to Parliament, or the issuance of warrants for surveillance activities by the police. In each case, departure from the traditional adjudicative determination of claims raised by litigants is thought to compromise the judicial purview under the separation of powers. ${ }^{6}$

The use of Australian judges in anti-terrorism legislative schemes is facilitated by an exception to this principle. A longstanding caveat to the strict separation of judicial power is that judges acting in a personal capacity, as personae designata, may assume official duties that vest in them as persons rather than as judges. ${ }^{7}$ Modern case law has qualified this exception by requiring that such extra-judicial service cohere with the judicial role under the Constitution, as determined by a doctrinal test of compatibility. ${ }^{8}$ The latter test requires, first, that a judge not assume so "permanent and complete" an extra-judicial function that his or her judicial duties are disrupted. ${ }^{9}$ The judge's ability to continue performing judicial duties with the requisite integrity must not be impaired, and the extra-judicial function must not be "of such a nature that public confidence in the integrity and impartiality in the judiciary [as a whole] . . . is diminished." ${ }^{10}$ Public confidence, in turn, will be found to have been vitiated should the extra-judicial function involve "too close a connection" between the appointee and the executive branch, should the function be subject to direction or advice from the political branches, or should any discretion exercised by the persona designata judge be based on grounds other than those prescribed by law. ${ }^{11}$ This doctrine has recently been extended to govern the extra-judicial activity of Australia's state and territorial judiciary. ${ }^{12}$

Consequently, when Australian judges are statutorily assigned new oversight functions related to the activities of security and intelligence officials, they assume these functions in an administrative capacity as individuals, not as judges. From a constitutional perspective, their powers must not conflict with the independence and integrity of the judiciary; but the powers nevertheless vest in them personally, not in the courts to which they belong.

Unlike their Australian counterparts, the unique jurisdiction of Canada's judiciary receives no express endorsement in textual provisions of the country's constitutional documents. Rather, Canada observes a functional separation of powers derived variously from the judicature provisions of the Constitution Act, 1867, ${ }^{13}$ which secure federal jurisdiction for the appointment of courts of inherent jurisdiction; ${ }^{14}$ the Charter of Rights and Freedoms, ${ }^{15}$ which requires, inter alia, that individuals charged with criminal offences be afforded independent and impartial judicial hearings $;{ }^{16}$ and from a broad, implied principle of judicial independence anchored in the preamble to the Constitution Act, 1867, which the Supreme Court has interpreted, controversially, ${ }^{17}$ to "fill out gaps"18 in constitutional text and to provide robust institutional and administrative safeguards for the judiciary. ${ }^{19}$ The terminology of "persona designata appointments" is largely alien to contemporary Canadian judicial practice. In 1985, the Supreme Court held in Minister of Indian Affairs $v$ Ranville ${ }^{20}$ that all statutory conferrals of authority on Canadian superior courts should be assumed to vest in them as courts, not in the judges as individuals, barring express legislative intention to the contrary. ${ }^{21}$

With the exception of judicial service in commissions of inquiry, on certain administrative tribunals, and in a small number of ceremonial administrative functions, ${ }^{22}$ Canadian judges thus assume new statutory powers and responsibilities qua judges. Importantly, they are also empowered with a constitutional instrument denied their Australian counterparts: an entrenched Charter of Rights, affording judges a basis to annul, sever, or read corrections into constitutionally-defective regimes successfully challenged by Charter litigants. The notion of judicial independence as it has been expressed in post-Charter Canadian jurisprudence is intimately tied to the role of judges as guardians of individual rights, since the judicial duty to safe- 
guard the Constitution embraces the rights-protections therein. ${ }^{23}$

These differences have intriguing implications for the involvement of Australian and Canadian judges in anti-terrorism regimes. Australia's approach produces a paradoxical situation in which departure from judicial norms (and the high standards of fairness that attend them) may reinforce the constitutional validity of new oversight functions. The doctrine of incompatibility requires that extra-judicial appointments be voluntary, ${ }^{24}$ that they involve observance of the basic elements of procedural fairness, ${ }^{25}$ and that they not involve decision-making on political grounds. ${ }^{26}$ Yet, the extra-judicial appointee is barred from behaving too judicially, lest he or she convert the proceeding into an actual judicial hearing, thus tramping on the principle that only courts may exercise judicial power. ${ }^{27}$ Australian judges thus have limited scope to leverage their authority in extra-judicial proceedings to require standards of due process approximating those of courts.

Following the terrorist attacks of 9/11, Australia amended the Australian Security Intelligence Organisation Act $1979^{28}$ to allow ASIO officers to seek investigative warrants authorizing the interrogation of individuals (including children aged 16-17 years) for up to 24 hours, ${ }^{29}$ and detention warrants authorizing detention of an individual for up to 7 days for the purposes of interrogation. ${ }^{30}$ Individuals subject to such warrants have no right to silence, no privilege against self-incrimination, and may be subjected to bodily and strip-searches. ${ }^{31}$ Their right to contact third parties, including legal representatives, is severely curtailed. ${ }^{32}$ Disclosure and noncompliance offences attaching to the regime are punishable by imprisonment. ${ }^{33}$ Serving federal, state, and territory judges play key roles in the warrant schemes. The warrants are issued by federal judges acting as personae designata. ${ }^{34}$ Once a warrant has been issued, the subject is immediately brought before a "prescribed authority" who oversees all exercises of power under the warrant. ${ }^{35}$ The prescribed authority may be a serving judge of a state or territory court acting persona designata. ${ }^{36}$
The troubling civil liberty implications of this regime have been aptly stated by Sir Gerard Brennan, former Chief Justice of the High Court: "a person may be detained in custody, virtually incommunicado without even being accused of involvement in terrorist activity, on grounds which are kept secret and without effective opportunity to challenge the basis of his or her detention." ${ }^{37}$ The outcome of a likely constitutional challenge under Chapter III is unclear, however. On the one hand, the regime presents a clear optic that the prescribed authority is acting in aid of the executive in facilitating an investigation. Interrogations under either an investigative or detention warrant occur in private. The judge acting persona designata is reliant on agents of the executive for the disclosure of information justifying issuance of the warrant, and cannot compel the production of evidence (either to herself or to the affected individual) during the interrogations. This informational imbalance - a significant departure from the traditional openness and adversarial rigour of a court - casts doubt on the judge's ability to ensure fairness and to act with true independence. The judge nevertheless exercises discretion independently in the sense that she remains master of the decision to grant a warrant, and may procedurally direct the interrogations by ordering an end to questioning or by requiring that the individual be represented by counsel, among other measures. ${ }^{38}$

Counter-intuitively, the case law may imply that the very features of the regime which are concerning - its secrecy and lack of adversarial testing of evidence - are the source of its constitutional validity. Most recently, in Wainohu $v$ New South Wales, ${ }^{39}$ the High Court invalidated a legislative scheme implicating state court judges in issuing control orders. The provisions compromised fair process by, for instance, involving secret evidence not governed by traditional rules. But, the powers were also exercised in proceedings with the appearance of open court, at which the applicant and respondent had an opportunity to put a case and test that of the other side. This, combined with the absence of a duty for the presiding judge to give reasons, proved constitutionally fatal: the appearance of open-court coupled with removal of the obligation to give reasons 
impermissibly undermined public confidence in the impartiality of the judiciary. ${ }^{40}$ Notably, past Chapter III jurisprudence has affirmed the validity of in camera, ex parte proceedings in which personae designata judges are similarly unencumbered by a duty to give reasons. ${ }^{41} \mathrm{~A}$ possible inference is that proceedings which observe less transparency to begin with, and less characteristic features of judicial probity and fairness, may be more likely to survive a Chapter III challenge because they do not invite analogies to the traditional judicial role.

This presents a striking contrast to the situation in Canada. Here, the interrelation of Charter rights with a broad independence principle has enabled courts to effectively "judicialize" counter-terrorism proceedings. This was evident in Charkaoui $v$ Canada (Citizenship and Immigration), ${ }^{42}$ where the Supreme Court invalidated a security certificate regime that denied judges the ability to adequately test the secret evidentiary claims of government officials, either through independent inquisitorial powers or through the adversarial claims of affected individuals. ${ }^{43}$ The resulting amendments to the regime, the constitutionality of which was recently affirmed in Canada (Citizenship and Immigration) $v$ Har$k a t,{ }^{44}$ brought it closer to an adversarial, adjudicative model by allowing for the appointment of special advocates to challenge secret evidence. In finding the amended regime compliant with section 7 of the Charter, the Court interpreted the new provisions in a manner that reinforced the judicial character of the proceedings. For example, the Court emphasized the role of designated judges as "gatekeepers", ensuring fairness to the individual subjects of security certificates and guarding vigilantly against government over-claiming of secrecy. ${ }^{45}$ Special advocates are to serve as "substantial substitutes" for participation in closed hearings by the affected individuals themselves. ${ }^{46}$ Moreover, the Court opined that special advocates should receive liberal authorization to communicate with affected individuals, the onus being on government to prove the necessity of restrictions on communication. ${ }^{47}$ Finally, designated judges are to ensure an "incompressible minimum" disclosure of information to the subjects of security certificates, enabling them to know the case to be met. ${ }^{48}$ Where the regime works an unfairness, designated judges retain the authority to issue remedies under section 24(1) of the Charter, including a stay of proceedings. ${ }^{49}$

In 2004, the Supreme Court upheld a regime of judicial investigative hearings which, in its purpose, largely parallels Australia's system of investigation and detention warrants. ${ }^{50}$ Crucially, the Court only did so after inferring the necessity of individual protections that rendered the regime compliant with the Charter and with the principle of judicial independence. Thus, while Canadian Superior Court judges may be enlisted to oversee coercive investigative hearings conducted by crown attorneys in furtherance of counter-terrorism measures, the individual subjects of such hearings benefit from procedural rights appropriate to a judicial forum. For example, judges will apply demanding criminal law standards of relevance to allow or disallow certain lines of questioning. ${ }^{51}$ Supplementing a statutory right for subjects to be represented by counsel, the Court specified that counsel must be afforded a "fulsome" opportunity to participate in the hearings, not limited to narrow grounds of objection. ${ }^{52}$ Despite the relatively narrow derivative-use immunity stipulated by the statute, the Court found that testimony given by subjects may not be admitted in any subsequent proceedings engaging their personal security, including extradition and deportation hearings. ${ }^{53}$ Perhaps most importantly, the Court held that the judicial status of the proceedings required presumptive application of the open-court principle: the hearings were to take place in public view, with the onus resting on the crown to demonstrate the necessity of publication bans or in camera hearings on a case-by-case basis, applying the standards applicable to all judicial hearings, including trials. ${ }^{54}$ It should be acknowledged that LeBel and Fish JJ both dissented from these findings. ${ }^{55}$ They disagreed with the majority position that judges have the requisite tools to enforce individual rights in the investigative hearings, and found the regime to compromise the institutional independence of the judiciary by generating a public perception of judges acting in aid of investigations carried out by the executive. ${ }^{56}$ 
While Australian judges cannot employ entrenched constitutional rights to enhance the fairness of legislative counter-terrorism schemes, they may still draw a valuable lesson from the Canadian courts' unselfconscious ability to absorb new powers qua courts, and thus exercise those powers in a way that is explicitly judicial. Specifically, the Australian judiciary might evoke the incompatibility doctrine to achieve similar judicializing effects as Canada's Charter, by treating core features of judicial procedure as fundamental to the independence of judges personae designata and to public confidence in the judiciary as a whole. This would be tantamount to declaring that where persona designata functions involve the oversight of coercive measures against individuals, court-like standards of due process are necessary to ensure constitutional validity. Such a declaration comes with the danger that the persona designata judge could be viewed as actually acting judicially, and thus in violation of Chapter III by having appropriated an administrative power to his or her court. The conferred power would be thereby annulled. Yet, this may be an unavoidable and necessary outcome: where the limits of judicialization are reached, judges may be forced to resort to principled renunciation in order to avoid conferring judicial legitimacy on processes whose curtailment of individual liberty is disproportionate to their stated security goals. In effect, the judges would be stating that such powers must be truly exercised judicially, or not exercised by judges at all.

Canadian judges may also take a lesson from their Australian counterparts. While the Charter empowers courts to render new judicial functions compliant with high procedural rights, the Canadian courts lack an analytic device comparable to the incompatibility doctrine to identify instances in which the acceptance of new powers (whether by individual judges or, in most cases, by the courts themselves) should be barred outright. Indeed, under the Canadian model, new statutory powers conferred on courts vest in them automatically and are exercised pursuant to the legislation's stated terms pending constitutional challenge. In Charkoui, the Supreme Court observed that judges under the original security certificate regime worked "assiduously" to over- come its defects. ${ }^{57}$ Of course, these efforts were inadequate to render the regime constitutionally compliant: hard work and principled motivation by the administrators of unconstitutional legislative powers won't save the legislation. Barring preemptive recognition and correction of its defects by Parliament, such legislation will await constitutional challenge. The fact that most new statutory powers vest in Australian judges personae designata, and that their assumption must be voluntary, means that those judges bear an ethical onus to scrutinize the constitutional propriety of an appointment before undertaking it. While in reality this duty may not always be exercised rigorously (otherwise there would be little need for subsequent constitutional challenges under Chapter III), it still presents an important threshold power which is absent in the Canadian context. That absence is troubling when one considers the odious effects that may be rendered by a regime - both upon individuals and upon confidence in the judiciary - while it awaits constitutional challenge.

This danger is acutely represented by Bill C-51. ${ }^{58}$ Among other concerning provisions, which have been extensively studied elsewhere, ${ }^{59}$ the Bill will empower CSIS officials to undertake undefined "measures," both within and outside Canada, to counteract threats to national security. ${ }^{60}$ When authorized by a warrant issued in private by a judge of the Federal Court, these measures may contravene Canadian law, including the Charter. ${ }^{61}$ Although the authorities seeking such a warrant must demonstrate its "reasonableness and proportionality," 62 and the Bill prohibits actions that inflict bodily harm, pervert the course of justice, or violate a person's sexual integrity, ${ }^{63}$ the purported empowerment of judges to preemptively authorize contravention of the law, let alone the country's highest law, is startling and unprecedented. As Professor Craig Forcese has observed: "What the government proposes now is a 'constitutional breach warrant.' It is a radical idea that contorts basic constitutional understandings and the role of the courts. It has been correctly compared to a stealth use of the notwithstanding clause, in which judges and not Parliament are being asked to do the dirty work of abrogating rights." ${ }^{\prime 4}$ 
When courts apply proportionality analysis under section 1 of the Charter to test the validity of legislation impinging on rights, they are exercising a designated role under the separation of powers to act as the final arbiter of legal rights, involving scrutiny of actual, enacted law. This is very different from judges secretly weighing the proportionality of measures proposed by executive actors, pronouncing on a preemptive basis whether they justify Charter "contravention." ${ }^{65}$ Such a function blurs the distinction between executive and judicial decision-making: it effectively places the judge in the shoes of an executive administrator, ascertaining whether a given circumstance warrants the displacement of legal norms for the exigencies of national security. It cannot truly be said that in doing so the courts are interpreting or applying law: applying a "law to authorize breaking the law" is a contradiction in terms. Its constitutionality is suspect on its face.

Yet this, in itself, is no bar to judges of the Federal Court acting under the legislation, should it become law, up until the point that it is successfully challenged by constitutional litigants. Moreover, even should those judges work in good faith to restrain arbitrary or excessive use of the power - as they did in applying the original, invalid legislation governing security certificates - this is no guarantee that affected individuals won't suffer constitutionally-invalid effects. This is especially the case when the very type of discretion judges are being asked to exercise appears to be at odds with the Charter, the separation of powers, and the principle of judicial independence itself. In the interim, public confidence in the judiciary may be eroded by the Federal Court's submission to legislative abrogation of the judicial role in safeguarding these values.

One clear solution, albeit a radical one, is highlighted by the Australian doctrine of incompatibility: the Federal Court, as an independent and administratively-distinct entity, could refuse to exercise the warrant issuing power altogether, treating it as a basic assault on its constitutional independence. The preemptive exercise of a Canadian court's authority over its internal administration has never, to our knowledge, been used to save judges from the exercise of inherently odious powers. But then, the courts have never been asked to sanction a breach of constitutional law in the manner envisaged by Bill $\mathrm{C}-51$. The extreme nature of the legislation may warrant an extreme and unprecedented judicial measure in response.

A comparison of Australian and Canadian judicial involvement in legislative counter-terrorism regimes leads us to conclude that judges in both countries face a dilemma best framed as one between judicialization and renunciation. Public confidence in judicial integrity derives not from a vague faith in the personal qualities of judges to do the right thing in the face of suspect powers, but from the institutional features of judicial decision-making that reinforce independence and impartiality: openness, fair process, high evidentiary standards, and fidelity to the Constitution, to name a few. If public confidence in the judiciary is the purported basis for judicial service in new oversight roles, then the institutional values which sustain it should follow judges to those settings. Conversely, settings in which legislators have chosen to abrogate those values are ill-suited to judicial service. Legislators have a prerogative to govern in the public interest, but forays into secrecy, coercive power, and suspended liberties are ones where judges shouldn't follow them.

\section{Notes}

* $\mathrm{PhD}$, of the Ontario Bar.

** PhD, Lecturer, TC Beirne School of Law, University of Queensland.

1 As put by the United States Supreme Court in Mistretta v United States 488 US 361 (1989) at 407 , the judicial reputation for independence and integrity should not be "borrowed by the political branches to cloak their work in the neutral colors of judicial action".

2 Bill C-51, An Act to enact the Security of Canada Information Sharing Act and the Secure Air Travel Act, to amend the Criminal Code, the Canadian Security Intelligence Service Act and the 
Immigration and Refugee Protection Act and to make Related and Consequential amendments to other Acts, 2nd Sess, 41st Parl, 2015.

$3 R v$ Kirby; Ex parte Boilermakers' Society of Australia, [1956] HCA 10, (1956) 94 CLR 254.

4 Ibid at para 3.

5 See Cheryl Saunders, The Australian Constitution (Carlton: Constitutional Centenary Foundation, 1997) at 76.

6 See e.g. In Re Judiciary and Navigation Acts (1921) 29 CLR 257, barring Australia's federal courts from issuing reference opinions. Judicial involvement in the authorization of police investigative practices is limited to judges acting persona designata, and pursuant to a doctrine of constitutional compatibility, explained in further detail below. See note $7 \mathrm{ff}$ and accompanying text.

7 For a history of this practice and its controversy, see AJ Brown, "The Wig or the Sword? Separation of Powers and the Plight of the Australian Judge" (1992) 21:1 Federal Law Review 48.

8 See especially Grollo v Palmer, [1995] HCA 26, 184 CLR 348 [Grollo], and Wilson v Minister for Aboriginal and Torres Strait Islander Affairs, [1996] HCA 18, 189 CLR 1 [Wilson].

9 Grollo, ibid at para 17

10 Grollo, ibid.

11 Wilson, supra note 8 at para 23.

12 See especially Wainohu $v$ New South Wales, [2011] HCA 24, 85 ALJR 746 [Wainohu], and discussion of this jurisprudential development in Rebecca Welsh, "Incompatibility Rising? Some Potential Consequences of Wainohu $v$ New South Wales" (2011) 22:4 Pub L Rev 251 at 263.

13 Constitution Act, 1867 (UK), 30 \& 31 Vict, c 3, reprinted in RSC 1985, App II, No 5.

14 Ibid at Part VII, ss 96-101.

15 Canadian Charter of Rights and Freedoms, Part I of the Constitution Act, 1982, being Schedule B to the Canada Act 1982 (UK), 1982, c 11.

$16 \mathrm{Ibid}$ at s 11(d). See also the Legal Rights provisions more generally at ss 7-14.

17 See e.g. Jeffrey Goldsworthy, "The Preamble, Judicial Independence, and Judicial Integrity" (2000) 11:2 Constitutional Forum 60; J Leclair, "Canada's Unfathomable Unwritten Constitutional Principles” (2002) 27:2 Queen's LJ 389; Warren J Newman, "'Grand Entrance Hall,' Back Door or Foundation Stone? The Role of Constitutional Principles in Construing and Applying the Constitution of Canada" (2001) 14 SCLR (2d) 197; and Mark D Walters, "The Common Law Constitution in Canada: Return of Lex Non Scripta as Fundamental Law" (2001) 51:2 UTLJ 91.
18 See the Supreme Court of Canada's decision in Reference re Remuneration of Provincial Judges, [1997] 3 SCR 3 at para 95, 150 DLR (4th) 577 [Provincial Judges Reference].

19 Provincial Judges Reference, ibid. Justice La Forest authored a strong dissent in the case, declaring: "The express provisions of the Constitution are not, as the Chief Justice contends, 'elaborations of the underlying, unwritten, organizing commitments found in the preamble to the Constitution Act, 1867. On the contrary, they are the Constitution. To assert otherwise is to subvert the democratic foundations of judicial review" (ibid at para 319).

20 Canada (Minister of Indian Affairs and Northern Development) $v$ Ranville, [1982] 2 SCR 518, 139 DLR (3d) 1 [Minister of Indian Affairs $v$ Ranville].

$21 \quad$ Ibid at 527.

22 For recent discussion of the service of Canadian judges in extra-judicial roles, see Patrick Monahan and Byron Shaw, "The impact of extra-judicial service on the Canadian judiciary: the need for reform" in HP Lee, ed, Judiciaries in Comparative Perspective (Cambridge: Cambridge University Press, 2011) 428.

23 Justice Major noted the breadth of contemporary constitutional values protected by judicial independence in Ell $v$ Alberta, 2003 SCC 35, [2003] 1 SCR 857 at para 22: "In modern times, it has been recognized that the basis for judicial independence extends far beyond the need for impartiality in individual cases. The judiciary occupies an indispensable role in upholding the integrity of our constitutional structure. . . . In Canada, like other federal states, courts ... serve to safeguard the constitutional distribution of powers. Courts also ensure that the power of the state is exercised in accordance with the rule of law and the provisions of our Constitution. In this capacity, courts act as a shield against unwarranted deprivations by the state of the rights and freedoms of individuals."

24 Grollo, supra note 8 at para 16.

25 Wilson, supra note 8 at para 23.

26 Ibid.

27 See Welsh, supra note 12.

28 Australian Security Intelligence Organisation Act 1979 (Cth), Part 3 Division 3 [ASIO Act].

29 Ibid at ss 34E(5)(b) and 34ZE.

$30 \mathrm{Ibid}$ at s 34. See discussion in Michael McHugh, "Terrorism Legislation and the Constitution" (2006) 28:2 Australian Bar Review 117.

31 See discussion in Jude McCulloch and Joo Cheong Tham "Secret State, Transparent Subject: The Australian Security Intelligence Organisation in 
the Age of Terror" (2005) 38:3 The Australian and New Zealand Journal of Criminology 400 at 402.

32 ASIO Act, supra note 28 at ss $34 \mathrm{~J}(1)(\mathrm{e}), 34 \mathrm{~K}(1),(9)$ (11), 34G(5)-(6), 34E(3), 34ZO, 34C(3B), 34D(4A), 34TA, 34U, 34CU. See also McCulloch and Tham, ibid, and Andrew Palmer, "Investigating and Prosecuting Terrorism: The Counter-Terrorism Legislation and the Law of Evidence" (2004) 27:2 UNSW L Rev 373 at 381.

33 ASIO Act, ibid at ss 34L, 34ZS. See also McCulloch and Tham, ibid, and Joo Cheong Tham, "Critique and Comment Casualties of the Domestic 'War on Terror': A Review of Recent Counter-Terrorism Laws" (2004) 28 Melb U L Rev 512.

34 ASIO Act, ibid at s 34AB.

35 Ibid at ss $34 \mathrm{H}, 34 \mathrm{~J}(3)$.

$36 \mathrm{Ibid}$ at s 34B.

37 Sir Gerard Brennan, "The Law and Justice Address" (Speech delivered at the Justice Awards, Parliament House, Sydney, 31 October 2007).

38 ASIO Act, supra note 28 at s $34 \mathrm{~K}(6)$.

39 Supra note 12.

40 Ibid at 192, 213, 215, 219-20, per French CJ and Keifel J.

41 See especially Grollo, supra note 8, and Justice Heydon's dissenting views in Wainohu, ibid at para 164.

42 Charkaouiv Canada (Citizenshipand Immigration), 2007 SCC 9, [2007] 1 SCR 350.

43 Ibid at paras 50-51. It should be noted that although the Court struck down the offending regime, it nevertheless suspended the effect of this declaration for a period of one year in order to allow Parliament to craft a legislative reply. In this sense, the Court did not exercise immediate remedial authority to reform the regime in a judicial mold. The Court's act of invalidation, and its identification of possible remedial alternatives, nevertheless led to this effect.

442014 SCC 37, [2014] 2 SCR 33.

45 Ibid at paras 46 and 64.

46 Ibid at para 47.

47 Ibid at para 70.

48 Ibid at paras 54-56.

49 Ibid at para 77.

50 See Application under $s 83.28$ of the Criminal Code (Re), 2004 SCC 42, [2004] 2 SCR 248 [Re s 83.28], and Vancouver Sun (Re), 2004 SCC 43, [2004] 2 SCR 332 [Vancouver Sun (Re)].

51 Re s 83.28, ibid at paras 50-54.

52 Ibid at para 47.

53 Ibid at para 79.

54 Vancouver Sun (Re), supra note 50; Re s 83.28, ibid at paras 103-104.
55 Re s 83.28, ibid at para $169 \mathrm{ff}$.

56 Ibid.

57 Supra note 42 at para 51.

58 Supra note 2.

59 Professors Craig Forcese and Kent Roach have provided extensive commentary on Bill C-51 as it passes through various stages of legislative review. Their complete commentary is available online at www.antiterrorlaw.ca.

60 Supra note 2 at s 42.

61 Ibid. The privacy of the warrant hearings is stipulated by s 48 , ibid.

62 Ibid.

63 Ibid.

64 Supra note 59. This statement is taken from: Craig Forcese, (Oral submissions to the Senate Standing Committee on National Security and Defence, 2 April 2015).

65 It is noteworthy that the legislation adopts the ambiguous term "contravene" as opposed to "violate" or "infringe." Under Canada's Charter jurisprudence, legislation may infringe rights and still be constitutionally valid when in pursuit of a pressing and substantial objective, and provided the scope of infringement is not disproportionate to that objective. Rights are violated when infringements cannot be justified in these terms, resulting in the annulment of the impugned legislation. By not using the term "infringe," the drafters of Bill C-51 appear to seek conferral of a power exceeding that characteristic of legislation whose Charter-adverse qualities can be justified under s 1 . They have nevertheless avoided adopting the very term - "violation" - that is eponymous with unconstitutionality in Charter jurisprudence. 